\title{
Impact of the Deep Sea Trawl Fishery on Demersal Communities of the Northern Tyrrhenian Sea (Western Mediterranean)
}

\author{
Paolo Sartor, Mario Sbrana and Bruno Reale \\ Centro Interuniversitario di Biologia Marina ed Ecologia Applicata \\ Viale N.Sauro 4, 57128 Livorno, Italy \\ and \\ Paola Belcari \\ Dipartimento Scienze Uomo e Ambiente \\ Università di Pisa, Via Volta 6, 56126 Pisa, Italy
}

\begin{abstract}
The composition of the catch of the deep sea trawl fleet of Porto Santo Stefano (northern Tyrrhenian Sea, western Mediterranean) was analysed. In the period 1995-99 observations were carried out on board commercial vessels, collecting data for about 500 trawling hours. Nephrops norvegicus, Parapenaeus longirostris and large specimens of Merluccius merluccius were the targets on the fishing grounds from 300 to $450 \mathrm{~m}$, while Aristaemorpha foliacea, Aristeus antennatus and $N$. norvegicus were targeted from 450 to $650 \mathrm{~m}$ depth.

By-catch dominated the biomass caught and it was characterized by a high degree of species richness, as a consequence of the reduced selectivity of the bottom trawl gear. An important fraction of the by-catch was made up of non-target commercial species, these providing an important added value to the landings. There was almost no discarding of target species. Annual average discards were about $20 \%$ of the total catch. Discarding of commercial species was mostly due to specimens under commercial size, while discarded non-commercial species included large numbers of small sized species of fishes and crustaceans. The results seem to indicate that this kind of fishery achieves a reasonable compromise between efficiency of resource utilisation and impact on the demersal communities.
\end{abstract}

Key words: by-catch, deep sea fishery, demersal ichthyofauna, discards, trawling, western Mediterranean

\section{Introduction}

In the Mediterranean basin, bottom trawling on the continental slope from about 250 to $800 \mathrm{~m}$ depth targeting decapod crustaceans with high economic value is an important fishery. In the western and central Mediterranean, Norway lobster (Nephrops norvegicus), red shrimps (Aristaeomorpha foliacea and Aristeus antennatus), deep-water rose shrimp (Parapenaeus longirostris) and also large sized specimens of European hake (Merluccius merluccius) are the target species of this fishery. In Italian waters these species accounted for an important fraction of commercial trawl landings. According to the national data series recorded by ISTAT (Italian Central Institute of Statistics), 57005 tons of Norway lobster, 43505 of red shrimps and 136243 of deep water rose shrimp were landed in the period 1985-96 (ISTAT, 1988-99).

Aspects of the biology and fishery of red shrimps and Norway lobster have been well documented in the Mediterranean Sea (Sardà, 1993, 1998; Bianchini and Ragonese, 1994), but the composition of the catch of these fisheries has not been analysed in detail.

The aim of the present study was to characterize the species composition of the catch, with particular attention to the by-catch, in order to evaluate the impact of this fishery on the demersal communities.

The study was performed in the northern Tyrrhenian Sea (western Mediterranean), where an 
important deep-sea trawl fishery is traditionally carried out by the Porto Santo Stefano and Porto Ercole fleets, on muddy bottoms from 300 to $650 \mathrm{~m}$ depth.

\section{Material and Methods}

In the years 1995-99 the activity of the commercial trawl fleet was monitored at Porto Santo Stefano, the main landing point of the area under investigation. This study focused on the portion of the fleet exploiting depths from 300 to $650 \mathrm{~m}$ depth. These vessels commonly employ bottom trawl nets with cod end mesh size (stretched) of about $40 \mathrm{~mm}$.

Fishing activity was monitored, on a seasonal basis, by observers on board commercial vessels. Monitoring activities did not interfere with the normal practice on board and modus operandi of the crew (e.g. allocation and duration of the haul, sorting of the catch).

Data on the species composition of the catch, subdivided by the fishermen into commercially retained and discarded fractions, were collected for each haul. In the sampled period, information from about 500 trawling hours was gathered. The collected data were analysed as hourly yields $(\mathrm{kg} / \mathrm{h})$ and then studied on a seasonal basis, according to the following categories (Alverson et al., 1994):

- Target species: commercial fraction of the target species.

- By-catch: fraction of the catch not belonging to the target species. into:

This latter category was subsequently divided

- Kept by-catch: portion of the catch landed together with the target species.

- Discarded by-catch: individuals caught but not retained; this fraction was then divided into Discard of commercial species (specimens either damaged or smaller than the commercial size) and Discard of non commercial species.

The Stock Use Efficiency (SUE) and the Ecological Use Efficiency (EUE) proposed by Alverson and Hughes (1996) were applied to evaluate the impact of by-catch on the total catch. These indices allow estimation of the retained fraction of the total catch, both in the case of a single target species (SUE) and in the case of a pool of commercial species (EUE):

Stock Use Efficiency (SUE, for each target species)

$$
=\frac{\sum \text { Commercial catch }}{\sum \text { Commercial catch }+\sum \text { Discarded catch }}
$$

Ecological Use Efficiency (EUE)

$$
=\frac{\sum_{\text {all species }} \text { Commercial catch }}{\sum_{\text {all species }} \text { Commercial catch }+\sum_{\text {all species }} \text { Catch }}
$$

\section{Results}

In the period studied, the trawl fleets of Porto Santo Stefano and Porto Ercole comprised 31 and 11 vessels, respectively (Table 1). The two fleets had similar characteristics except for average engine power, which was higher for the Porto Santo Stefano boats. Deep sea trawling was usually carried out by 13 vessels, 8 at Porto Santo Stefano and 5 at Porto Ercole.

Observations on board of Porto Santo Stefano trawlers allowed the identification of different fishing areas, at depths greater than $300 \mathrm{~m}$, localised between the Isles of Giglio and Montecristo and to the south of Pianosa Island (Fig. 1). On the fishing grounds from 300 to $450 \mathrm{~m}$ depth the most important target species was Norway lobster; other targets were deep water rose shrimp and large sized specimens of European hake (greater than $25 \mathrm{~cm}$ of total length). These "Norway lobster fishing grounds" were exploited all year round; usually, two hauls were performed on each fishing day, with mean duration of $4 \mathrm{hr} 14 \mathrm{~min}( \pm 35 \mathrm{~min})$ each.

Other fishing grounds were localized at greater depths, from about 450 to $650 \mathrm{~m}$, with the two red shrimps and Norway lobster as target species. The fishing activity on these bottoms ("red shrimp fishing grounds") was mostly carried out from spring to autumn. Because of the low fishing effort by the fleet in winter, no data were available for this season. On each fishing day two hauls were usually performed, with a mean duration of $4 \mathrm{hr} 56 \mathrm{~min}( \pm 38 \mathrm{~min})$ each.

In all, 155 species were recorded in the period studied, 86 fishes, 20 cephalopods, 41 crustaceans and 8 belonging to other taxa. Two distinct faunistic assemblages could be detected from analysis of the 
TABLE 1. Main characteristics of the otter trawl fleets of the two ports.

\begin{tabular}{lcccc}
\hline \hline \multicolumn{1}{c}{ Port } & $\begin{array}{c}\text { Number of } \\
\text { vessels }\end{array}$ & $\begin{array}{c}\text { Mean kw } \\
( \pm \text { S.E. })\end{array}$ & $\begin{array}{c}\text { Mean Gross Registered } \\
\text { Tonnage }( \pm \text { S.E. }), \text { tons }\end{array}$ & $\begin{array}{c}\text { Mean Overall Length } \\
( \pm \text { S.E. }), \text { meters }\end{array}$ \\
\hline Porto Santo Stefano & 31 & $\begin{array}{c}347.6 \\
( \pm 23.8)\end{array}$ & 55.4 & $\begin{array}{c}( \pm 7.1) \\
( \pm 0.8)\end{array}$ \\
Porto Ercole & \multirow{2}{*}{11} & $\begin{array}{c}219.4 \\
( \pm 19.8)\end{array}$ & 55.6 & 21.1 \\
& & $( \pm 5.9)$ & $( \pm 1.3)$ \\
\hline
\end{tabular}

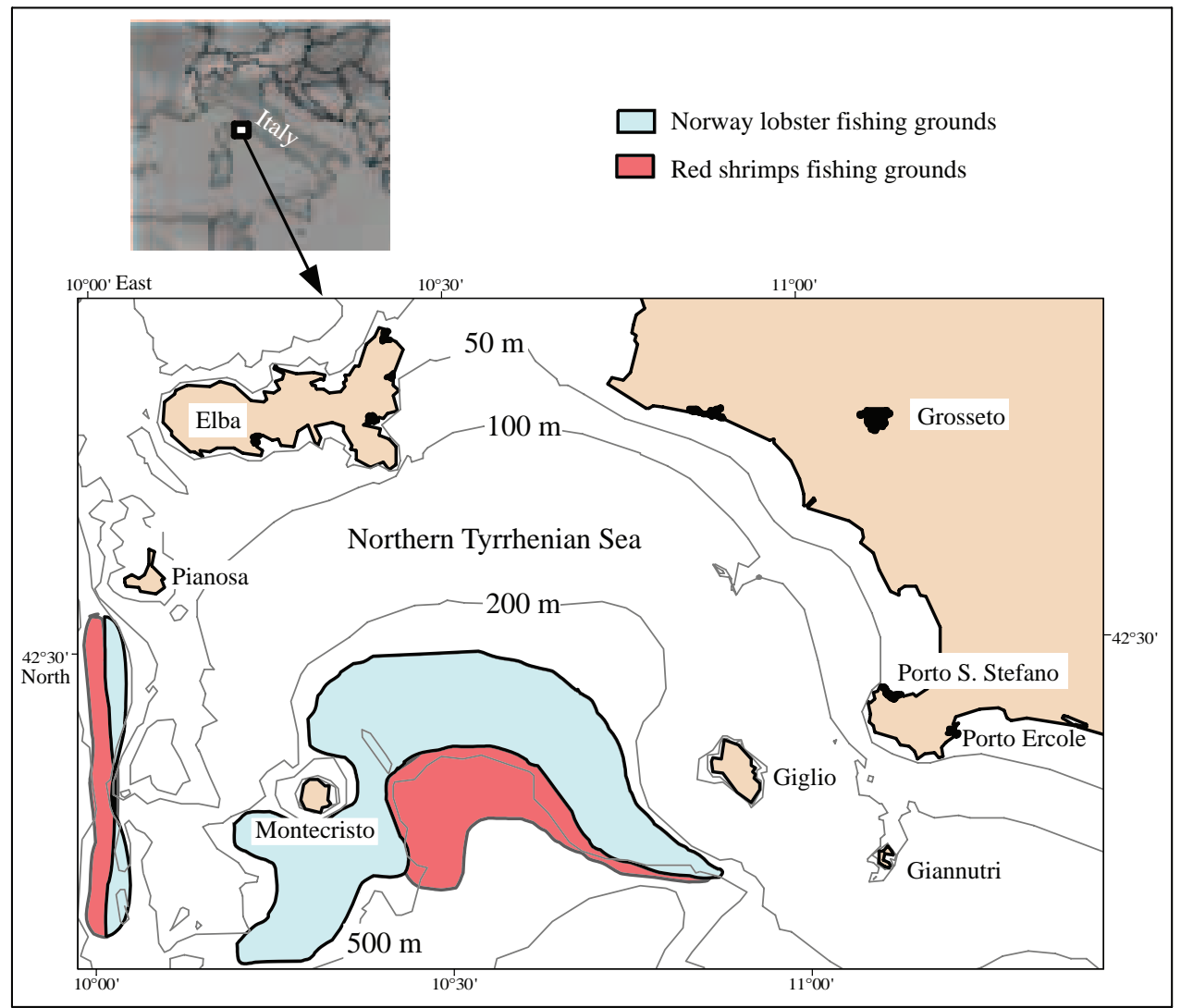

Fig. 1. Fishing grounds of the deep-sea trawl fleets of Porto Santo Stefano and Porto Ercole.

species composition of the catch, according to the different fishing grounds (Table 2): the "Norway lobster fishing grounds" yielded 147 species, while 96 species were collected from the "red shrimp fishing grounds". Even though 90 species were common to the two assemblages, most of these showed a different abundance in each fishing area.

In all seasons, the target species represented an important fraction of the total catch, from 14 to $30 \%$ (from 5.2 to $6.7 \mathrm{~kg} / \mathrm{hr}$ ) in the shallower fishing grounds and from 20 to $46 \%$ (from 3.4 to $5.3 \mathrm{~kg} / \mathrm{hr}$ ) in the deeper grounds (Fig. 2). Norway lobster yields showed a peak in spring at shallower depths, and another in autumn at greater depths; yields of deep-water rose shrimp and the red shrimps (A. foliacea and A. antennatus) reached maximum values in spring, while the catches of large sized specimens of European hake were more abundant in winter (Table 3).

By-catch dominated the biomass caught, in all seasons and in both fishing grounds. The most 
TABLE 2. List of species and mean yields in weight $(\mathrm{kg} / \mathrm{hr})$ obtained in the study period in the different fishing grounds according to the fractions of the catch.

\begin{tabular}{|c|c|c|c|c|c|c|c|c|}
\hline & Norwa & lobster & fishing g & ounds & Red & imps & hing gr & unds \\
\hline & 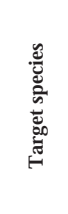 & 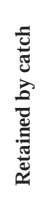 & 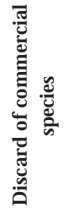 & 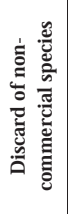 & 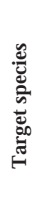 & 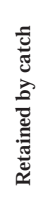 & 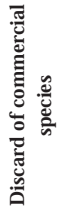 & 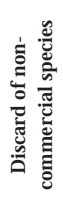 \\
\hline $\begin{array}{l}\text { Nephrops norvegicus } \\
\text { prapensirestris }\end{array}$ & & & & & & & & \\
\hline $\begin{array}{l}\text { Parapenaeus Iongirostris } \\
\text { Aristaeomorpha foliacea } \\
\text { Aristeus antennatus }\end{array}$ & & & & & & & & \\
\hline Merluccius merluccius & & & & & & & & \\
\hline $\begin{array}{l}\text { FISHES } \\
\text { Acantholabrus palloni }\end{array}$ & & & & & & & & \\
\hline $\begin{array}{l}\text { Acantholabrus palloni } \\
\text { Antonogadus megalokynoc }\end{array}$ & & & & & & & & \\
\hline Argentina sphyraena & & & & & & & & \\
\hline Arnoglossus rueppelli & & & & & & & & \\
\hline Bellottia apoda & & & & & & & & \\
\hline Benthosema glaciale & & & & & & & & \\
\hline Callionymus maculatus & & & & & & & & \\
\hline Capros aper & & & & & & & & \\
\hline Centracanthus cirrhus & & & & & & & & \\
\hline Centrolophus niger & & & & & & & & \\
\hline Ceratoscopelus maderensi & & & & & & & & \\
\hline Chauliodus sloani & & & & & & & & \\
\hline Chimaera monstrosa & & & & & & & & \\
\hline Chlorophthalmus agassizi & & & & & & & & \\
\hline Citharus linguatula & & & & & & & & \\
\hline Coelorhynchus coelorhync & & & & & & & & \\
\hline Conger conger & & & & & & & & \\
\hline Dalatias licha & & & & & & & & \\
\hline Diaphus metopoclampus & & & & & & & & \\
\hline Diaphus rafinesquei & & & & & & & & \\
\hline Echelus myrus & & & & & & & & \\
\hline Echiodon dentatus & & & & & & & & \\
\hline Epigonus constanciae & & & & & & & & \\
\hline Epigonus denticulatus & & & & & & & & \\
\hline Epigonus telescopus & & & & & & & & \\
\hline Etmopterus spinax & & & & & & & & \\
\hline Gadella maraldi & & & & & & & & \\
\hline Gadiculus argenteus & & & & & & & & \\
\hline Galeus melastomus & & & & & & & & \\
\hline Glossanodon leioglossus & & & & & & & & \\
\hline Gnathophis mystax & & & & & & & & \\
\hline Gobius niger & & & & & & & & \\
\hline Helicolenus dactylopterus & & & & & & & & \\
\hline Hexanchus griseus & & & & & & & & \\
\hline Hoplostethus mediterranet & & & & & & & & \\
\hline Hymenocephalus italicus & & & & & & & & \\
\hline Lampanyctus crocodilus & & & & & & & & \\
\hline Lepidopus caudatus & & & & & & & & \\
\hline Lepidorhombus boscii & & & & & & & & \\
\hline Lepidorhombus whiffiagor & & & & & & & & \\
\hline Lesueurigobius friesii & & & & & & & & \\
\hline Lesueurigobius suerii & & & & & & & & \\
\hline Lophius budegassa & & & & & & & & \\
\hline Lophius piscatorius & & & & & & & & \\
\hline Macroramphosus scolopax & & & & & & & & \\
\hline $\begin{array}{l}\text { Maurolicus muelleri } \\
\text { Microichthys coccoi }\end{array}$ & & & & & & & & \\
\hline Micromesistius poutassou & & & & & & & & \\
\hline Molva dipterygia & & & & & & & & \\
\hline Mora moro & & & & & & & & \\
\hline Mullus surmuletus & & & & & & & & \\
\hline Nemichthys scolopaceus & & & & & & & & \\
\hline $\begin{array}{l}\text { Nettastoma melanurum } \\
\text { Nezumia sclerorhynchus }\end{array}$ & & & & & & & & \\
\hline
\end{tabular}


TABLE 2. (Continued). List of species and mean yields in weight ( $\mathrm{kg} / \mathrm{hr}$ ) obtained in the study period in the different fishing grounds according to the fractions of the catch.

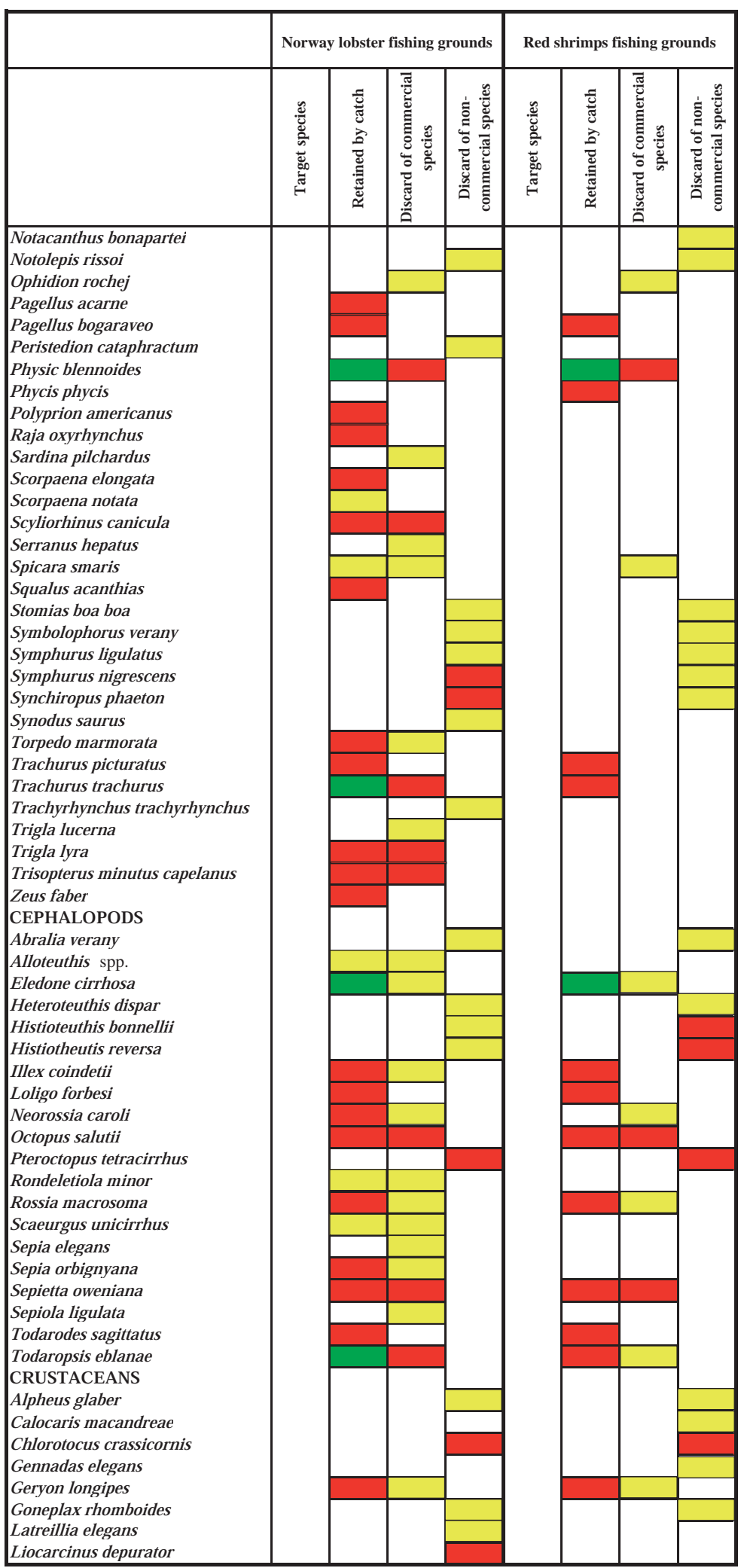


TABLE 2. (Continued). List of species and mean yields in weight ( $\mathrm{kg} / \mathrm{hr}$ ) obtained in the study period in the different fishing grounds according to the fractions of the catch.

\begin{tabular}{|c|c|c|c|c|c|c|c|c|}
\hline & \multicolumn{4}{|c|}{ Norway lobster fishing grounds } & \multicolumn{4}{|c|}{ Red shrimps fishing grounds } \\
\hline & 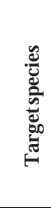 & 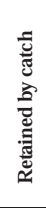 & 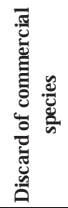 & 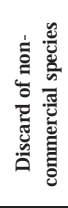 & 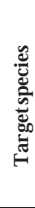 & 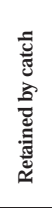 & 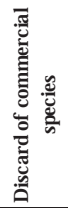 & 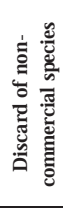 \\
\hline \begin{tabular}{|l} 
Macropipus tuberculatus \\
Macropodia longipes \\
Macropodia rostrata \\
Medorippe lanata \\
Monodaeus couchi \\
Munida intermedia \\
Munida tenuimana \\
Pagurus alatus \\
Pagurus prideauxi \\
Parasquilla ferussaci
\end{tabular} & & & & & & & & \\
\hline $\begin{array}{l}\text { Paromola cuvieri } \\
\text { Pasiphaea multidentata }\end{array}$ & & & & & & & & \\
\hline $\begin{array}{l}\text { Pasiphaea sivado } \\
\text { Philocheras echinulatus } \\
\text { Plesionika acanthonotus } \\
\text { Plesionika antigai }\end{array}$ & & & & & & & & \\
\hline Plesionika edwardsii & & & & & & & & \\
\hline $\begin{array}{l}\text { Plesionika giglioli } \\
\text { Plesionika heterocarpus }\end{array}$ & & & & & & & & \\
\hline $\begin{array}{l}\text { Plesionika martia } \\
\text { Policheles typhlops }\end{array}$ & & & & & & & & \\
\hline $\begin{array}{l}\text { Pontocaris cataphracta } \\
\text { Pontocaris lacazei }\end{array}$ & & & & & & & & \\
\hline $\begin{array}{l}\text { Pontophilus spinosus } \\
\text { Processa canaliculata }\end{array}$ & & & & & & & & \\
\hline $\begin{array}{l}\text { Processa nouveli } \\
\text { Rissoides pallidus } \\
\text { Sergestes arcticus }\end{array}$ & & & & & & & & \\
\hline Solenocera membranacea & & & & & & & & \\
\hline $\begin{array}{l}\text { OTHERS } \\
\text { Alcyonium palmatum }\end{array}$ & & & & & & & & \\
\hline $\begin{array}{l}\text { Aporrhais pespelecani } \\
\text { Astropecten irregularis }\end{array}$ & & & & & & & & \\
\hline $\begin{array}{l}\text { Cassidaria echinofora } \\
\text { Cavolinia tridentata }\end{array}$ & & & & & & & & \\
\hline Pennatula rubra & & & & & & & & \\
\hline $\begin{array}{l}\text { Pyrosoma atlanticum } \\
\text { Terebratula vitrea }\end{array}$ & & & & & & & & \\
\hline NUMBER OF SPECIES & 3 & 52 & 42 & 85 & 3 & 31 & 28 & 58 \\
\hline
\end{tabular}

\begin{tabular}{|l|}
\hline \multicolumn{2}{|c|}{ Yields } \\
\hline \\
$\begin{array}{l}<0.1 \mathrm{~kg} / \mathrm{h} \\
\text { from } 0.1 \text { to } 0.5 \mathrm{~kg} / \mathrm{hr} \\
\text { from } 0.5 \text { to } 1.0 \mathrm{~kg} / \mathrm{hr} \\
\text { from } 1.0 \text { to } 2.5 \mathrm{~kg} / \mathrm{hr} \\
\text { from } 2.5 \text { to } 4.0 \mathrm{~kg} / \mathrm{hr}\end{array}$ \\
\hline
\end{tabular}

important fraction of by-catch was represented by commercial species (kept by-catch), with hourly yields between 10.5 and $23.6 \mathrm{~kg} / \mathrm{hr}$ on the shallower grounds and between 4.3 and $10.5 \mathrm{~kg} / \mathrm{hr}$ on the deeper grounds (Fig. 2). The maximum values were always observed in summer. The by-catch mostly consisted of fishes and cephalopods, the most abundant species were blue whiting (Micromesitius poutassou), greater forkbeard (Phycis blennoides), small specimens of European hake and horned octopus (Eledone cirrhosa), on the 

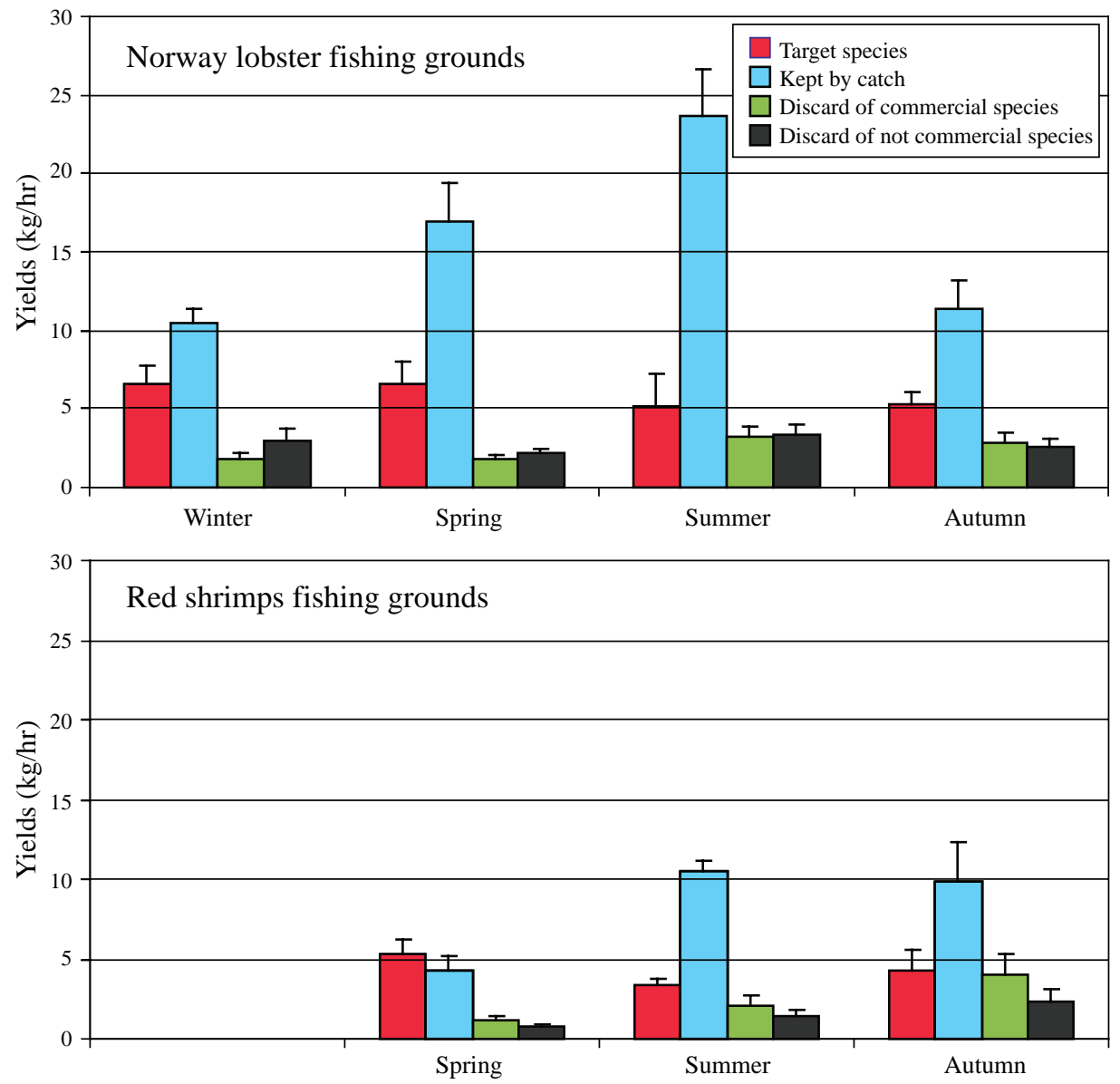

Fig. 2. Seasonal mean yields-per-hour $(\mathrm{kg} / \mathrm{hr})$ of each fraction of the catch obtained in the different fishing grounds.

TABLE 3. Seasonal mean yields-per-hour (with standard error) of the target species obtained in the different fishing grounds.

\begin{tabular}{|c|c|c|c|c|c|}
\hline Target species & \multicolumn{2}{|c|}{ Winter } & Spring & Summer & Autumn \\
\hline \multicolumn{6}{|c|}{ Norway lobster fishing grounds } \\
\hline N. norvegicus & 2.777 & $(0.313)$ & $3.456 \quad(0.765)$ & $2.231(0.303)$ & $2.969(0.595)$ \\
\hline P. longirostris & 1.743 & $(0.500)$ & $2.127 \quad(0.965)$ & $1.791(0.297)$ & $1.125(0.333)$ \\
\hline M. merluccius ${ }^{1}$ & 2.138 & $(0.554)$ & $1.035 \quad(0.252)$ & $1.174(0.211)$ & $1.232(0.173)$ \\
\hline \multicolumn{6}{|c|}{ Red shrimp fishing grounds } \\
\hline A. foliacea & - & - & $3.274 \quad(0.765)$ & $0.837(0.535)$ & $0.973(0.954)$ \\
\hline A. antennatus & - & - & $0.505 \quad(0.061)$ & $0.324(0.301)$ & $0.053(0.051)$ \\
\hline N. norvegicus & - & - & $1.512(0.351)$ & $2.260(0.768)$ & $3.248(1.894)$ \\
\hline
\end{tabular}

${ }^{1}$ large sized specimens $(>25 \mathrm{~cm}$ of total length) 


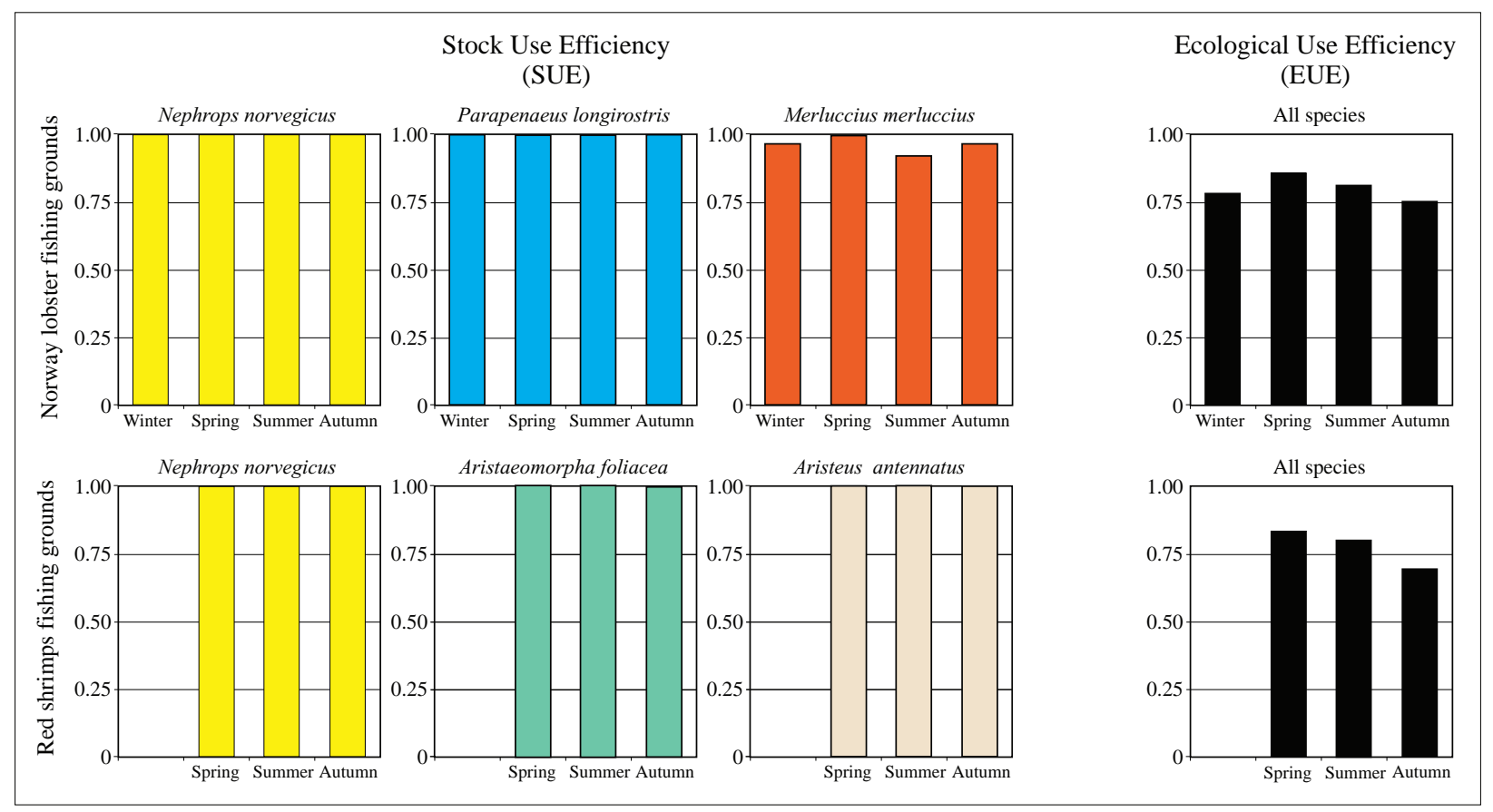

Fig. 3. Values of Stock Use Efficiency (SUE) and of Ecological Use Efficiency (EUE) computed for the catches obtained in the different fishing grounds, for each season.

"Norway lobster fishing grounds", greater forkbeard, blackmouth catshark (Galeus melastomus), and European hake on the "red shrimp fishing grounds" (Table 2).

As shown by the values of the EUE index, discards constituted a considerable fraction of the total catch, ranging from 14.5 to $24.6 \%$ and from 16.9 to $30.9 \%$ in the shallower and deeper areas, respectively (Fig. 3).

Discarding of commercial species was mostly due to presence of specimens of fishes and cephalopods which were too small to be marketed. Although there was a large number of species in this fraction, the biomass was mostly due to blackmouth catshark accounting for $32 \%$ on the shallower grounds and for $62 \%$ on the deeper grounds (Table 2 ).

The discards of non-commercial species were the fraction with the highest species richness from both fishing grounds. They were mostly fishes and crustaceans. Most of the species were of small size, less than $10 \mathrm{~g}$ individual weight; thus, their importance was higher in terms of abundance than biomass. On the shallower fishing grounds, the silvery pout (Gadiculus argenteus) accounted for $62 \%$ of the non- commercial catch, while on the deeper fishing grounds the biomass of this fraction was more equally shared among the 63 species caught.

Discarding of target species was negligible, as shown by the SUE index values (Fig. 3). Effectively, the entire catch of the four species of crustaceans was landed. Discarding of European hake was low and limited to small specimens, which would have been unmarketable; the maximum discard rate was reached in summer on the shallower fishing grounds $(0.08$ $\mathrm{kg} / \mathrm{hr}$ corresponding to the $8 \%$ of the total catch of this species).

\section{Discussion}

Most fishing techniques involve unavoidable impact on the marine communities, especially those techniques producing catches of species or specimens different from those targeted by the fishery. The term "by-catch" is used in the present paper, in agreement with Alverson et al. (1994), to refer to this non-target fraction of the catch, although other authors have given a different definition of this term (Hall, 1996). As used in this paper the by-catch consists of commercially retained species and also non marketable species, which are rejected at sea. 
The review by Alverson et al. (1994) gives an idea on the magnitude of this problem, showing that each type of fishery, gear and habitat has its own by-catch problems; in particular, about 27 million tons of marine organisms are discarded each year, corresponding to roughly one third of the annual landings reported by FAO. Estimation of quantity and composition of the by-catch is one of the most important research priorities, not only for fishery assessment purposes (Mesnil, 1996) but also as an important tool to evaluate the biological impact of fisheries (Commission of the European Communities, 1994).

In recent decades, several trawlers of Porto Santo Stefano and Porto Ercole, the main fishing ports of the northern Tyrrhenian Sea, have specialised in carrying out deep-water bottom trawling all year round on the continental slope. The results showed that fishing is carried out on two main fishing grounds differing both in species assemblage and target species. Some seasonality was detected in exploitation of the different fishing grounds and in yields of the target species, the major species being Norway lobster, which is in great demand on local markets (average annual first sale price of about 22 Euro $/ \mathrm{kg}$ ). In winter the deeper fishing grounds (greater than $450 \mathrm{~m}$ ) were less exploited due to low yields of target species (especially Norway lobster). Therefore, in winter the fishing effort was concentrated on a narrower depth range, where the highest yields of large specimens of European hake were also observed, in accordance with the reproductive biology of the species (Biagi et al., 1995). For the red shrimp (A. foliacea) and the deep-water rose shrimp the maximum yields observed in spring were probably a consequence of the distribution pattern; in particular, in spring the larger specimens of deep-water rose shrimp concentrate for reproduction at depths greater than $200 \mathrm{~m}$ (Mori et al., 1986; Levi et al., 1995).

The results obtained in this study showed that the by-catch of the deep sea trawl fishery in the northern Tyrrhenian Sea (western Mediterranean) accounted for about $80 \%$ of the total annual average catch, while the remaining fraction was constituted by target species. Even though exploitation is devoted to the target species, the economic value of the landing is also enhanced by species belonging to the retained bycatch. This is an important characteristic of the Mediterranean trawl fishery which can be classified as multispecific (Caddy, 1993). Furthermore, on many fishing grounds landings are dominated by small sized species, most of which have considerable local im- portance, such as small specimens of horned octopus exploited on the continental shelf (Belcari et al., 1998). For these reasons, bottom trawl gears have low selectivity in the Mediterranean area. Increasing the mesh size to more than the legal size of $40 \mathrm{~mm}$ would result in loss of many small species from catch that have significant economic value (Caddy, 1993). In addition long haul duration, such as that observed in this study, can reduce mesh selectivity, thereby increasing discard rates (Murawski, 1996).

In our results, the presence of small sized specimens was recorded predominantly in the non commercial by-catch, the retained by-catch being mostly composed of medium-large sized species (e.g. blue whiting, greater forkbeard and horned octopus). This kind of fishery produces a significant amount of discard, representing about $20 \%$ of the total catch on the different fishing grounds. An even greater proportion of discard was reported by Moranta et al. (2000) for the same type of fishery in the Balearic Islands, corresponding to $42 \%$ of the total biomass caught.

Discard of commercial species was mostly constituted by individuals under the commercial size of species belonging to the commercially retained bycatch. Discard was particularly frequent in cases of low commercial value species, such as the blackmouth catshark. Discarding of target species was practically absent, confirming the high efficiency of their exploitation. In contrast, on the continental shelf fishing grounds of the same area the discard of target species may reach high levels, as documented for European hake in summer (about 35\%, Sartor et al., 2001).

The low selectivity of the gear as well as the species diversity of the exploited fish assemblages are the main reason for the high species richness detected in the catches, especially as regards the discarded fraction. This may produce an "ecosystem level impact" (Hall, 1996) on a complex of species belonging to the demersal communities. Unfortunately, most of these species may be included in the "by-catch of unknown levels" as indicated by Hall (1996), because there is still a lack of information on their abundance and mortality rate which does not allow estimation of the sustainability of the impact of the fishing activity considered in the present study.

The results obtained seem to indicate a reasonable compromise between efficiency of resource utilization and impact on the demersal communities. However, some strategies to reduce mortality of small sized 
specimens, such as increasing the cod end mesh size and/or other technical measures (e.g. escape windows with square meshes), could be proposed to improve the sustainability of this kind of fishery.

\section{Acknowledgements}

The authors thank the crew of the Porto Santo Stefano vessels and the fishermens' associations for their collaboration during the study. This work was carried out with financial assistance from the Commission of the European Communities (contracts ref. DG-XIV MED94/0267 and DGXIV MED97/0068).

\section{References}

ALVERSON, D. L., M. H. FREEBERG, J. G. POPE, and S. A. MURAWSKY. 1994. A global assessment of fisheries by-catch and discard. FAO Fish. Tech. Pap., 339, 233 p.

ALVERSON, D. L., and S. E. HUGHES. 1996. By-catch: from emotion to effective natural resource management. Rev. Fish. Biol. and Fish., 6: 443-462.

BELCARI, P., P. SARTOR, and S. DE RANIERI. 1998. I cefalopodi nello sbarcato commerciale con reti a strascico nel Mar Tirreno Settentrionale. Biol. Mar. Medit., 5(2): 318-325.

BIAGI, F., A. CESARINI, M. SBRANA, and C. VIVA. 1995. Reproductive biology and fecundity of Merluccius merluccius (Linnaeus, 1758) in the northern Tyrrhenian Sea. Rapp. Comm. Int. Mer Médit., 34: 237.

BIANCHINI, M. L., and S. RAGONESE (eds.). 1994. Life cycles and fisheries of the deep-water red shrimps Aristaeomorpha foliacea and Aristeus antennatus. Proceedings of the International Workshop held in the Istituto di Tecnologia della Pesca e del Pescato (ITPP - CNR), Mazara del Vallo, Italy, 28-30 April '94. N.T.R.I.T.P.P. Special Publications, 3, $88 \mathrm{p}$.
CADDY, J. F. 1993. Some future perspectives for assessment and management of Mediterranean fisheries. Sci. Mar., 57 (2-3): 121-130.

COMMISSION OF THE EUROPEAN COMMUNITIES. 1994. Report on the meeting on data base for evaluation of biological impact of fishery. Commission Staff Working Paper, $39 \mathrm{p}$.

HALL, M. A. 1996. On bycatches. Rev. Fish Biol. and Fish., 6: $319-352$.

ISTAT (Istituto Centrale di Statistica). 1988-1999. Statistiche della caccia e della pesca.

LEVI, D., M. G. ANDREOLI, and R. M. GIUSTO. 1995. First assessment of the rose shrimp, Parapenaeus longirostris (Lucas, 1846) in the central Mediterranean. Fish. Res., 21: 375-393.

MESNIL, B. 1996. When discard survive: accounting for survival of discards in fisheries assessment. Aquat. Living Resour., 9: 209-215.

MORANTA, J., E. MASSUTÍ, and B. MORALES-NIN. 2000. Fish catch composition of the deep-sea decapod crustacean fisheries in the Balearic Islands (western Mediterranean). Fish. Res., 45: 253-264.

MORI, M., P. BELCARI, and F. BIAGI. 1986. Distribuzione e sex-ratio di Parapenaeus longirostris (Lucas) nel Tirreno Settentrionale. Nova Thalassia, 8 (Suppl. 3): 623-625.

MURAWSKI, S. A. 1996. Factors influencing by-catch and discards rates: analyses from multispecies/multifisheries sea sampling. J. Northw. Atl. Fish. Sci., 16:31-89.

SARDÀ, F. 1993. Bio-ecological aspects of the decapod crustacean fisheries in the western Mediterranean. Aquat. Living Resour., 6: 299-305.

SARDÀ, F. (ed.). 1998. Nephrops norvegicus: comparative biology and fishery in the Mediterranean Sea. Sci. Mar., 62 (Suppl. 1): 143 p.

SARTOR, P., M. SARTINI, B. REALE, and M. SBRANA. 2001. Analysis of the discard practices in the Merluccius merluccius L., (1758) bottom trawl fishery of the northern Tyrrhenian Sea. Biol. Mar. Medit., 8 (1): 771-774. 